Chirurgia (2019) 114: 147-151

No. 2, March - April

Copyright@ Celsius

http://dx.doi.org/10.21614/chirurgia.114.2.147

\title{
Past, Present and Future in Colorectal Surgery
}

\author{
Viorel Scripcariu \\ Faculty of Medicine, "Grigore T Popa" University of Medicine and Pharmacy, Iași, Romania \\ $1^{\text {st }}$ Surgical Oncology Unit, Regional Institute of Oncology, Iași, Romania
}

Corresponding author:

Professor Viorel Scripcariu

Faculty of Medicine, "Grigore T Popa"

University of Medicine and Pharmacy, lași, Romania

1st Surgical Oncology Unit, Regional Institute of Oncology, lași, Romania

E-mail: vscripcariu@gmail.com
Colorectal cancer is a major health issue all over the world and, during the last century hass seen great improvements in colorectal cancer management.

The interest for rectal pathology has been established even from Hippocrates' era $(1,2)$. In the $19^{\text {th }}$ century, the management of rectal cancer was based on a colostomy, first time described in 1776 by Jean Zulema Amussat. In 1826 Jacques Lisfranc successfully performed the first resection for rectal cancer, removing only a few centimeters of the distal rectum, procedure published in 1833 (3).

In 1908 in Lancet, Sir Ernest Miles published a new method of performing abdomino-perineal excision for carcinoma of the rectum and the terminal segment of the pelvic colon, considered "one of the most formidable operations in surgery" with a mortality of $41.6 \%$ (4). Too much conservatism in the removal of the organ associated with a high rate of local recurrence were the arguments for a new technique (5).

In 1917 Arthur D. Bevan published a paper which described the posterior approach to the rectum by complete division of the anal sphincters in the midline and coccygectomy, technique that later was recognized as Bevan procedure (6).

William Bashall Gabriel (1893-1975) proposed a 1-stage procedure called "perineo-abdominal excision of the rectum" and in 1934 Martin Kirschner first imagined a technique that allowed two surgical teams to work at the same time. A combined lithotomy-Trendelenburg position enabled Lloyd-Davies in 1939 to perform the first synchronous combined radical abdominoperineal resection using adjustable leg support (3).

In 1930 Dukes describes the possible dissemination pathways for cancer of the rectum and a new classification of 
rectal cancer is proposed, which represents a modification of the clinical classification into A, B, and C stages (7). In 1977 the first TNM staging Cancer Manual was elaborated by the American Joint Committee on Cancer (AJCC) and is used until present time in patient management (8).

J. C. Goligher in 1937 in the book "Surgery of the Anus, Rectum and Colon", gives information about causes, treatment of colorectal cancer and the new techniques used at that moment (9).

In 1948 in Annals of Surgery, Claude F. Dixon, first describes the anterior resection for malignant lesions of the upper part of the rectum and lower part of the sigmoid with a resectability rate of $80 \%$ for tumors higher than $10 \mathrm{~cm}$ from the dentate line and $44 \%$ for tumors at $8 \mathrm{~cm}$, with a mortality rate of $5.9 \%(10)$.

In 1982 Krause described the abdominoperineal excision of the rectum presenting details of both perineal and abdominal approaches, but this intervention was associated with a high rate of urinary tract complication, of up to $25 \%$ (11).

An important step in the treatment of rectal cancer is achieved in 1986, when Heald publishes the survival results after total mesorectal excision in rectal cancer (12) and in 1988 when he describes the "Holy plane in rectal surgery", showing that local recurrences are the most important reflection of surgical technique in rectal cancer (13). A total mesorectal excision (TME) is performed by dissection of the mesorectum down to the plane of the levator ani, with its removal that must be made with an intact mesorectal fascia, based on a sharp dissection. In Heald's first series of 112 patients, the rate of local recurrence was $2 \%$, as compared to $20 \%$ in conventional rectal resection (12-17).

In 1986, Philip Quirke, first shows through histopathological studies that in rectal adenocarcinoma, local recurrence is mainly due to lateral spread of the tumour, aspect that was underestimated before (18).

Neoadjuvant radiotherapy treatment effi ciency was first proven in 1997 when the results from the Swedish trial were published, showing a recurrence rate of $11 \%$ for patients with short course radiotherapy, compared to $27 \%$ in patients with upfront surgery (19). In 2001 in the Danish trial, the local recurrence rate was reported to be $5 \%$ in the radiotherapy group, compared to $11 \%$ in the surgery group (20).

TME associated with neoadjuvant chemoradiotherapy represents a major progress in rectal cancer in the last decades. In 1994 TME was introduced in Stockholm and after a training project, the permanent stoma rate was reduced from $60.3 \%$ to $26.5 \%(\mathrm{P}<0.001)$, five-year local recurrence rates decreased from $21.9 \%$ to $8.2 \%(\mathrm{P}<0.001)$ and five-year cancerspecific survival rates increased from $66.0 \%$ to $77.3 \%(\mathrm{P}<0.001)(21)$.

Based upon the necessity of a multidisciplinary approach for patients with rectal cancer in March 2003, in England was launched the first English National Multidisciplinary Team- Total Mesorectal Excision (MDT-TME) Development Program, which was the first MDT program. Through education and development of colorectal MDTs, the project proposed to improve survival and quality of life of patients with rectal cancer. The core members of each MDT (Radiologists, Oncologists, Colorectal Surgeons, Pathologists and Colorectal Nurses) were involved in the multidisciplinary management of patients in all phases of the treatment (22).

According to the concept of TME for rectal cancer, a concept of complete mesocolic excision (CME) for colonic cancer was proposed. It consists of the separation of the mesocolon from the parietal plane and true central ligation of the supplying arteries and draining veins at their roots. The technique is associated with a reduced 5-year local recurrence from $6.5 \%$ to $3.6 \%$ and an increased 5-year survival rate from $82.1 \%$ to 89.1\% (23). The Toldt fascial plane allows a dissection for a precise conduction of $\mathrm{CME}$, using a correct technique $(24,25)$.

A wait-and-watch strategy for patients with rectal cancer and complete clinical response after neoadjuvant radio-chemotherapy was proposed by the Habr-Gama in her studies with organ preservation in selected cases. This is quite a bold approach and may 
be considered when radical surgery is not immediately performed and an attentive screening for local relapse is conducted. A strict follow-up program may yield a rate of up to $70 \%$ of patients without surgery during surveillance. Thus, similar oncological outcomes may be obtained both through this strategy and through surgery only, with the benefit of avoiding mortality and morbidity associated to rectal surgery (26-33). However, this approach needs more study.

A minimally invasive approach for rectal cancer surgery may be performed through laparoscopy, robotic surgery, NOTES (natural orifice transluminal endoscopic surgery), or TAMIS (transanal minimally invasive surgery) with high-quality local excision in selected cases.

TaTME (transanal TME) represents a valuable alternative to standard, transabdominal TME, in obese male patients with distal, locally advanced rectal cancer and seems to revolutionize the practice of rectal cancer surgery in these cases (34-39).

In early-stage rectal cancer (cT1-3N0M0), organ preservation is possible with TEM (transanal endoscopic microsurgery) or TEO (transanal endoscopic operation) in approximately two-thirds of patients, with good long-term oncological outcomes and quality of life (40).

Robotic assisted surgery for rectal cancer is associated with an acceptable morbidity and a low rate of positive circumferential resection margins. An European consensus in order to validate the TME robotic technique was published in 2018 (41,42). Both laparoscopic and robotic TME, were proven feasible and the results in terms of oncological outcomes are similar to open surgery, but provide shortterm benefits. Robotic surgery allows by means of a better visualization, an improved nerve sparing and a direct entry in the dissection plane (43).

New biomarkers are necessary in order to predict colorectal cancer survival, and among these, the immune system plays a very important role. Although TNM staging is considered to be the most important prognostic factor, immunologic criteria seem to have a prognostic value that was proven to be superior and independent of the TNM staging system. Team of Franck Pages and Jerome Galon has shown that local immune reaction and the presence of high levels of infiltrating memory cells are correlated with the absence of signs of early metastatic invasion, a less advanced pathological stage and increased survival. The immunological data (type, density, and location of immune cells within the tumor) are better predictors of patient survival than the histopathological findings used in staging colorectal cancer (44-49). In 2018 in Lancet was published the international validation for the Immunoscore as prognostic marker in colorectal cancer (50). In rectal cancer the prognostic value of immune infiltration was proved based on a diagnostic biopsy analysis, with a better response to neoadjuvant treatment in patients with high levels of infiltration $(51,52)$.

Surgery will continue to be influenced by technology and innovation. No matter the choice of surgical approach, the oncological radicality of colorectal cancer surgery has to represent the gold standard in patient management (53).

\section{Conflict of Interest}

The author declare no conflicts of interests.

\section{References}

1. Glase S. Hippocrates and Proctology. Proc roy Soc Med. 1969;62(4):380-1.

2. Michael, Graney C. Colorectal surgery from antiquity to the modern era. Dis Colon Rectum. 1980;23(8):582.

3. Campos FG, Habr-Gama A, Sergio C, Rodrigo N, Perez 0. Abdominoperineal Excision: Evolution of a Centenary Operation. Dis Colon Rectum. 2012;55(8):844-53.

4. Miles WE et al. A Method of Performing Abdomino Perineal Excision for Carcinoma of the Rectum and of the Terminal Portion of the Perlvic Colon. Lancet. 1812;1812-3.

5. Wiley MJ, Rieger N. Audit and the birth of the abdomino-perineal excision for carcinoma of the rectum. ANZ J Surg. 2003;73(10): 858-61.

6. Criado F, Wilson T. Posterior Transsphincteric Approach for Surgery of the Rectum- The Bevan Operation. Dis Colon Rectum. 1981;24(3):145-50.

7. Gordon-Watson C. DC. The treatment of carcinoma of the rectum with radium. With an introduction on the spread of cancer of the rectum. Br J Surg [Internet]. 1930; Available from: http://onlinelibrary.wiley.com/doi/10.1002/bjs.1800176810/abstract

8. Carr DT. The manual for the staging of cancer. Ann Intern Med. 1977;87(4):491-2. 
9. Reviews and Notices of Books. $\mathrm{Br} \mathrm{J}$ Inebr [Internet]. 1937; 34(4):166-95. Available from: http://dx.doi.org/10.1111/ j.13600443.1937.tb05500.x

10. Dixon CF. Anterior resection for malignant lesions of the upper part of the rectum and lower part of the sigmoid. Ann Surg. 1948; 128(3):425-42.

11. Krause U, Pțhlman L, Thorén L. Abdominoperineal excision. World J Surg. 1982;6(5):549-53.

12. Heald RJ, Ryall RDH. Recurence and survival after total mesorectal excision for rectal cancer. Lancet. 1986;327(8496):1479-82.

13. Heald RJ. The ' Holy Plane' of rectal. J R Soc Med. 1988; 81(September):503-8.

14. Madoff RD. The uses of surgical history. Dis Colon Rectum 2012;55(8):829-30.

15. Macfarlane JK, Ryall RDH, Heald RJ. Mesorectal excision for rectal cancer. Lancet. 1993;341(8843):457-60.

16. Heald RJ, Husband EM, Ryall RDH. The mesorectum in rectal cancer surgery - the clue to pelvic recurrence? Br J Surg. 1982; 69(10):613-6.

17. Heald RJ, Moran BJ, Ryall RDH, Sexton, Rosemary MacFarlane JK The Basingstoke Experience of Total Mesorectal Excision, 1978199. Arch Surg. 1998;133(8):894-9.

18. Quirke P, Dixon MF, Durdey P, Williams NS. Local Recurrence of Rectal Adenocarcinoma Due To Inadequate Surgical Resection. Lancet. 1986;328(8514):996-9.

19. Size S. Improved Survival with Preoperative Radiotherapy in Resectable Rectal Cancer. N Engl J Med [Internet]. 1997;336(14): 980-7. Available from: http://www.nejm.org/doi/abs/ 10.1056/ NEJM199704033361402

20. Kapiteijn E, Marijnen CAM, Nagtegaal ID, Putter H, Steup WH, Wiggers T, et al. Preoperative Radiotherapy Combined with Total Mesorectal Excision for Resectable Rectal Cancer. N Engl J Med [Internet]. 2001;345(9):638-46. Available from: http://www.nejm. org/doi/abs/10.1056/NEJMoa010580

21. Martling A, Holm T, Rutqvist LE, Johansson H, Moran BJ, Heald RJ, et al. Impact of a surgical training programme on rectal cancer outcomes in Stockholm. Br J Surg. 2005;92(2):225-9.

22. Jessop J, Beagley C, Heald RJ. The Pelican Cancer Foundation and The English National MDT-TME Development Programme. Colorectal Dis. 2006;8 Suppl 3:1-2.

23. Hohenberger W, Weber K, Matzel K, Papadopoulos T, Merkel S. Standardized surgery for colonic cancer: Complete mesocolic excision and central ligation - Technical notes and outcome. Color Dis. 2009;11(4):354-64.

24. Benz S, Tannapfel A, Tam Y, Grünenwald A, Vollmer S, Stricker I. Proposal of a new classification system for complete mesocolic excison in right-sided colon cancer. Tech Coloproctol [Internet]. 2019;0(0):0. Available from: http://dx.doi.org/10.1007/s10151019-01949-4

25. Liang JT, Huang J, Chen TC, Hung JS. The Toldt fascia: A historic review and surgical implications in complete mesocolic excision for colon cancer. Asian J Surg [Internet]. 2019;42(1):1-5. Available from: https://doi.org/10.1016/j.asjsur.2018.11.006

26. Habr-Gama A, Săo Juliăo GP, Vailati BB, Castro I, Raffaele D. Management of the Complete Clinical Response. Clin Colon Rectal Surg. 2017;30(5):387-94.

27. Spolverato G, Pucciarelli S, Bertorelle R, de Rossi A, Nitti D. Predictive factors of the response of rectal cancer to neoadjuvant radiochemotherapy. Cancers (Basel). 2011;3(2):2176-94.

28. Belluco C, De Paoli A, Canzonieri V, Sigon R, Fornasarig M, Buonadonna $A$, et al. Long-term outcome of patients with complete pathologic response after neoadjuvant chemoradiation for cT3 rectal cancer: Implications for local excision surgical strategies. Ann Surg Oncol. 2011;18(13):3686-93.

29. Glynne-Jones R, Hughes R. Critical appraisal of the "wait and see" approach in rectal cancer for clinical complete responders after chemoradiation. Br J Surg. 2012;99(7):897-909.

30. Habr-Gama A, Perez RO. Non-operative management of rectal cancer after neoadjuvant chemoradiation. Br J Surg. 2009;96(2): 125-7.

31. Habr-Gama A, Sabbaga J, Gama-Rodrigues J, Săo Juliăo GP, Proscurshim I, Bailăo Aguilar P, et al. Watch and Wait Approach Following Extended Neoadjuvant Chemoradiation for Distal Rectal Cancer. Dis Colon Rectum [Internet]. 2013;56(10):1109-17. Available from: http://content.wkhealth.com/linkback/openurl?sid $=$ WKPTLP:landingpage \&an=00003453-201310000-00001

32. Habr-Gama A, Săo Juliăo GP, Perez RO. Nonoperative management of rectal cancer: Identifying the ideal patients. Hematol Oncol Clin North Am [Internet]. 2015;29(1):135-51. Available from: http://dx.doi.org/ 10.1016/j.hoc.2014.09.004

33. Habr-Gama A, Oliva Perez R. La stratégie « attendre et surveiller» chez les patients ayant un cancer du bas rectum avec une réponse clinique complète après radiochimiothérapie néoadjuvante. J Chir (Paris). 2009;146(3):237-9.

34. Lacy AM, Tasende MM, Delgado S, Fernandez-Hevia M, Jimenez M, De Lacy B, et al. Transanal Total Mesorectal Excision for Rectal Cancer: Outcomes after 140 Patients. J Am Coll Surg [Internet]. 2015;221(2):415-23. Available from: http://dx.doi.org/10.1016/ j.jamcollsurg.2015.03.046

35. Zhang H, Zhang YS, Jin XW, Li MZ, Fan JS, Yang ZH. Transanal single-port laparoscopic total mesorectal excision in the treatment of rectal cancer. Tech Coloproctol. 2013;17(1):117-23.

36. Atallah S, Albert M, Debeche-Adams T, Nassif G, Polavarapu H, Larach S. Transanal minimally invasive surgery for total mesorectal excision (TAMIS-TME): A stepwise description of the surgical technique with video demonstration. Tech Coloproctol. 2013; 17(3):321-5.

37. Lacy AM, Adelsdorfer C, Delgado S, Sylla P, Rattner DW. Minilaparoscopy-assisted transrectal low anterior resection (LAR): A preliminary study. Surg Endosc. 2013;27(1):339-46.

38. Leroy J, Barry BD, Melani A, Mutter D, Marescaux J. No-scar transanal total mesorectal excision: The last step to pure NOTES for colorectal surgery. JAMA Surg. 2013;148(3):226-30.

39. Heald RJ. A new solution to some old problems: transanal TME. Tech Coloproctol. 2013:17(3):257-8.

40. Stijns RCH, de Graaf EJR, Punt CJA, Nagtegaal ID, Nuyttens JJME, van Meerten E, et al. Long-term Oncological and Functional Outcomes of Chemoradiotherapy Followed by Organ-Sparing Transanal Endoscopic Microsurgery for Distal Rectal Cancer. JAMA Surg. 2018;154(1):47

41. Miskovic D, Ahmed J, Bissett-Amess R, Gómez Ruiz M, Luca F, Jayne $D$, et al. European consensus on the standardization of robotic total mesorectal excision for rectal cancer. Color Dis. 2018;21(3):270-6.

42. Hara M, Sng K, Yoo BE, Shin JW, Lee DW, Kim SH. Robotic-assisted surgery for rectal adenocarcinoma: Short-term and midterm outcomes from 200 consecutive cases at a single institution. Dis Colon Rectum. 2014;57(5):570-7

43. Weaver KL, Grimm LM, Fleshman JW. Changing the way we manage rectal cancer-standardizing TME from open to robotic (Including Laparoscopic). Clin Colon Rectal Surg. 2015;28(1): 28-37.

44. Zinzindohoué F, Zeitoun G, Berger A, Todosi AM, Marliot F, Lagorce $\mathrm{C}$, et al. [Immunology and personalized medicine in oncology]. Bull Cancer. 2014;101 Suppl:12-7.

45. Tosolini M, Kirilovsky A, Mlecnik B, Fredriksen T, Mauger S, Bindea $G$, et al. Clinical impact of different classes of infiltrating T cytotoxic and helper cells (Th1, Th2, Treg, Th17) in patients with colorectal cancer. Cancer Res. 2011;71(4):1263-71.

46. Fridman WH, Galon J, Pagès $F$, Tartour $E$, Sautès-Fridman C, 
Kroemer G. Prognostic and predictive impact of intra- and peritumoral immune infiltrates. Cancer Res. 2011;71(17):5601-5.

47. Mlecnik $B$, Bindea $G$, Pagès $F$, Galon J. Tumor immunosurveillance in human cancers. Cancer Metastasis Rev. 2011;30(1):5-12.

48. Angell H, Galon J. From the immune contexture to the Immunoscore: The role of prognostic and predictive immune markers in cancer. Curr Opin Immunol. 2013;25(2):261-7.

49. Bindea G, Mlecnik B, Fridman WH, Galon J. The prognostic impact of anti-cancer immune response: a novel classification of cancer patients. Semin Immunopathol. 2011;33(4):335-40.

50. Pagès $F$, Mlecnik $B$, Marliot $F$, Bindea $G, 0 u F S$, Bifulco $C$, et al. International validation of the consensus Immunoscore for the classification of colon cancer: a prognostic and accuracy study. Lancet. 2018;391(10135):2128-39.

51. Anitei M-G, Zeitoun G, Mlecnik B, Marliot F, Haicheur N, Todosi A-
$\mathrm{M}$, et al. Prognostic and Predictive Values of the Immunoscore in Patients with Rectal Cancer. Clin Cancer Res [Internet]. 2014 Apr 1;20(7):1891-9. Available from: http://www.embase.com/search/ results?subaction=viewrecord\&from $=$ export\&id $=\mathrm{L} 372785950 \% 0 \mathrm{~A}$ http://dx.doi.org/10.1158/1078-0432.CCR-13-2830\%0A http://sfx.library.uu.nl/utrecht?sid=EMBASE\&issn=15573265\&id= doi:10.1158\%2F1078-0432.CCR-13-2830\&atitle=Prognostic tand+

52. McMullen TPW, Lai R, Dabbagh L, Wallace TM, De Gara CJ. Survival in rectal cancer is predicted by $T$ cell infiltration of tumourassociated Iymphoid nodules. Clin Exp Immunol. 2010;161(1): 81-8.

53. de Lacy FB, Chadi SA, Berho M, Heald RJ, Khan J, Moran B, et al. The Future of Rectal Cancer Surgery: A Narrative Review of an International Symposium. Surg Innov. 2018;25(5):525-35. 